\title{
Expression of AS3MT alters transcriptional profiles in human urothelial cells exposed to arsenite
}

\author{
SD Hester ${ }^{1}$, Z Drobná ${ }^{2}$, DMK Andrews ${ }^{3}, \mathbf{J ~ L i u}^{4}$, MP Waalkes ${ }^{4}$, DJ Thomas ${ }^{5}$, and M Stýblo 2,6 \\ ${ }^{1}$ Cancer Biology Branch, ECD, NHEERL, US EPA, RTP, North Carolina \\ ${ }^{2}$ Department of Nutrition, University of North Carolina, Chapel Hill, North Carolina \\ ${ }^{3}$ Microarray Core, NIEHS, RTP, North Carolina \\ ${ }^{4}$ Inorganic Carcinogenesis, LCC, National Cancer Institute at NIEHS \\ ${ }^{5}$ Pharmacokinetics Branch, ETD, NHEERL, US EPA, RTP, North Carolina \\ ${ }^{6}$ Center for Environmental Medicine, Asthma, and Lung Biology; University of North Carolina, \\ Chapel Hill, North Carolina
}

\begin{abstract}
Inorganic arsenic (iAs) is an environmental toxicant and human carcinogen. The enzymatic methylation of iAs that is catalyzed by arsenic ( +3 oxidation state)-methyltransferase (AS3MT) generates reactive methylated intermediates that contribute to the toxic and carcinogenic effects of iAs. We have shown that clonal human urothelial cells (UROtsa/F35) that express rat AS3MT and methylate iAs are more susceptible to acute toxicity of arsenite (iAs ${ }^{\mathrm{III}}$ ) than parental UROtsa cells that do not express AS3MT and do not methylate iAs. The current work examines transcriptional changes associated with AS3MT expression and identifies specific categories of genes expressed in UROtsa and UROtsa/F35 cells in response to a 24-h exposure to 1 or $50 \mu \mathrm{M}$ iAs ${ }^{\mathrm{III}}$. Here, the expression of 21,073 genes was assessed using Agilent Human 1A(V2) arrays. Venn analysis showed marked concentration-dependent differences between gene expression patterns in UROtsa and UROTsa/F35 cells exposed to iAs ${ }^{\mathrm{III}}$. Among 134 genes altered by exposure to subtoxic $1 \mu \mathrm{M}$ iAs ${ }^{\mathrm{III}}$, only 14 were shared by both cell lines. Exposure to cytotoxic $50 \mu \mathrm{M}$ iAs ${ }^{\mathrm{III}}$ uniquely altered 1389 genes in UROtsa/F35 and 649 genes in UROtsa cells; 5033 altered genes were associated with the chemical alone. In UROtsa, but not UROtsa/F35 cells exposure to $1 \mu \mathrm{M}$ iAs ${ }^{\mathrm{III}}$ altered expression of genes associated with cell adhesion. In contrast, expression of genes involved in cell cycle regulation was significantly altered in UROtsa/F35 cells at this exposure level. At $50 \mu \mathrm{M}$ iAs ${ }^{\mathrm{III}}$, pathways regulating cell cycle, cell death, transcription, and metabolism were affected in both cell lines. However, only Urotsa/F35 cells showed numerous G-protein and kinase pathway alterations as well as alterations in pathways involved in cell growth and differentiation. These data link the AS3MT-catalyzed methylation of iAs to specific genomic responses in human cells exposed to iAs ${ }^{\mathrm{III}}$. Further analysis of these responses will help to characterize the role of AS3MTcatalyzed methylation in modulation of iAs ${ }^{\mathrm{III}}$ toxicity.
\end{abstract}

\section{Keywords}

arsenite; AS3MT; human urothelial cells; transcriptional profiles

\footnotetext{
(C) 2009 SAGE Publications

Correspondence to: Dr Susan D. Hester, Cellular Toxicology Branch, Environmental Carcinogenesis Division, U. S. Environmental Protection Agency, B143-06, 109 T.W. Alexander Drive Research Triangle Park, NC 27711. Express Mail: 4930 Page Road, Durham, NC 27703. hester.susan@epa.gov.
} 


\section{Introduction}

The enzymatic methylation of inorganic arsenic (iAs) is the major pathway for metabolism of iAs in humans and in many other mammalian species. ${ }^{1,2}$ Arsenic (+3 oxidation state)methyltransferase (AS3MT) is the key enzyme in this pathway. ${ }^{3,4}$ The methylation of iAs by human AS3MT yields methylarsenic (MAs) and dimethylarsenic (DMAs) metabolites that contain arsenic (As) in either +5 oxidation state $\left(\mathrm{As}^{\mathrm{V}}\right)$ or +3 oxidation state $\left(\mathrm{As}^{\mathrm{III}}\right){ }^{5,6}$ The toxicity of each of these metabolites differs significantly from toxicities of iAs species. In general, iAs species, for example, arsenite (iAs ${ }^{\mathrm{III}}$ ) or arsenate $\left(\mathrm{iAs}^{\mathrm{V}}\right)$, are an order of magnitude more toxic than methylated pentavalent arsenicals (MAs ${ }^{\mathrm{V}}$ or DMAs $\mathrm{V}$ ), but less toxic than methylated trivalent arsenicals (MAs ${ }^{\mathrm{III}}$ or DMAs ${ }^{\mathrm{III}}$ ). ${ }^{7-9}$ Thus, the adverse outcomes of acute or chronic exposures to iAs depend in part on the amounts and the ratios of various metabolites produced in the AS3MT-catalyzed reactions and retained in target tissues.

AS3MT is expressed in rat and human hepatocytes that are efficient methylators of iAs, ${ }^{10}$ but not in SV-40 transformed normal human urothelial (UROtsa) cells that do not methylate iAs. ${ }^{11}$ To examine the role of AS3MT-catalyzed methylation in the toxicity of iAs exposure, we have recently created a genetically modified UROtsa cell line (UROtsa/F35) that expresses rat AS3MT and methylates iAs. ${ }^{11}$ When exposed to iAs ${ }^{\mathrm{III}}$ UROtsa/F35 cells produce MAs ${ }^{\mathrm{III}}, \mathrm{MAs}^{\mathrm{V}}$, DMAs ${ }^{\mathrm{III}}$, and DMAs ${ }^{\mathrm{V}}$. Our previous work has shown that UROtsa/ F35 cells are more sensitive than the parent UROtsa cells to acute toxicity of iAs ${ }^{\mathrm{III}} .{ }^{11}$

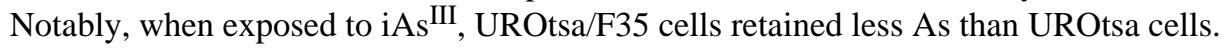
However, a significant portion of As retained by UROtsa/F35 cells is represented by methylated metabolites of iAs ${ }^{\mathrm{III}}$. These metabolites are absent in the parent UROtsa cells that lack AS3MT activity. Thus, the increased susceptibility of UROtsa/F35 cells to iAs ${ }^{\mathrm{III}}$ is associated with the production and cellular retention of methylated arsenicals.

The goal of the present study was to compare gene expression patterns in UROtsa and UROtsa/F35 cells before and after exposure to subtoxic or toxic concentration of iAs ${ }^{\mathrm{III}}$ and to identify specific transcriptional responses associated with the expression of AS3MT and with the production of methylated arsenicals in UROtsa/F35 cells. Because this study was designed as a pilot study with limited number of samples, we elected to examine the resulting transcriptional results on a cellular pathway level as opposed investigating individual genes. Our data show significant quantitative and qualitative differences between the transcriptional profiles in UROtsa and UROtsa/F35 cells exposed to either subtoxic or toxic concentration of iAs ${ }^{\mathrm{III}}$. The character of genomic responses specific for UROtsa/F35 cells suggest that at low exposure levels, the AS3MT-catalyzed methylation of iAs is associated with changes in pathways regulating cell cycle and nucleotide metabolism. At high exposure levels, the methylation of iAs affects mainly G-protein- and protein kinasemediated pathways, as well as pathways involved in cell growth and differentiation. Taken together, these results show that genomic responses would differ in cells or tissues with different capacities to methylate iAs and in cells or tissues exposed to different iAs metabolites. This work provides additional evidence that the enzymatic methylation of iAs plays a key role in determining the adverse outcomes associated with either acute or chronic exposures to iAs.

\section{Material and methods}

\section{Cell lines and treatments}

UROtsa cells, which are SV-40 transformed normal human urothelial cells, were obtained from Dr Unimye (Department of Urology, West Virginia University). The clonal UROtsa/ F35 cell line expressing rat AS3MT was created from the parent UROtsa cell line, using a 
retroviral pLEGFP-N1 gene delivery system. ${ }^{11}$ Both UROtsa and UROtsa/F35 cells were cultured in MEM (GIBCO BRL, Grand Island, New York, USA) medium supplemented with $10 \%$ FBS (GIBCO BRL), penicillin (50 U/ml, Sigma, St. Louis, Missouri, USA), and streptomycin $(50 \mu \mathrm{g} / \mathrm{ml}$, Sigma). Cells were cultured in 60-mm diameter culture dishes (Falcon, Becton Dickinson Labware, Lincoln Park, New Jersey, USA) at $37^{\circ} \mathrm{C}$ in a humidified incubator in a $95 \%$ air $/ 5 \% \mathrm{CO}_{2}$ atmosphere. Confluent cell cultures were serum starved for $16 \mathrm{~h}$ prior to exposure to iAs ${ }^{\mathrm{III}}$. To characterize the metabolic activity of UROtsa and UROtsa/F35 cultures, serum starved cells were incubated with 1 or $50 \mu \mathrm{M}\left[{ }^{73} \mathrm{As}\right] \mathrm{iAs}{ }^{\mathrm{III}}$ for $24 \mathrm{~h}$ in a cell culture incubator as previously described. ${ }^{11}$ Radiolabeled metabolites were then analyzed in $\mathrm{CuCl}$-treated cell lysates and cell culture media by thin-layer chromatography (TLC). ${ }^{12}$ Both cell lysate and media were oxidized by hydrogen peroxide before TLC analysis. This method determines total iAs (iAs $\left.{ }^{\mathrm{III}}+\mathrm{iAs}^{\mathrm{V}}\right)$, total MAs $\left(\mathrm{MAs}^{\mathrm{III}}+\right.$ $\mathrm{MAs}^{\mathrm{V}}$ ), and total DMAs (DMAs ${ }^{\mathrm{III}}+\mathrm{DMAs}^{\mathrm{V}}$ ). For microarray analysis, both UROtsa and UROtsa/F35 cells were exposed for $24 \mathrm{~h}$ to 1 or $50 \mu \mathrm{M}$ of non-radioactive iAs ${ }^{\mathrm{III}}$, sodium salt (Sigma).

\section{RNA isolation, microarray hybridization, and quality control}

The expression of 21,073 genes was assessed in UROtsa and UROtsa/F35 cells before and after exposure to iAs ${ }^{\mathrm{III}}$, using Agilent Human 1A(V2) arrays (Agilent Technologies, Palo Alto, California, USA). Total RNA for the microarray analysis was isolated using TRIzol (Invitrogen Life Technologies, Inc., Carlsbad, California, USA), followed by purification and DNase-I digestion on RNeasy columns (Qiagen, Valencia, California, USA). Quality of the isolated RNA was assessed by Agilent 2100 Bioanalyzer (Agilent Technologies). Total RNA was amplified using the Agilent Low RNA Input Fluorescent Linear Amplification Kit. The cyanine (Cy)3- and Cy5-labeled cRNA were produced from 500 ng of total RNA, following the manufacturer's protocol. For each two-color comparison, 750 ng each of Cy3and Cy5-labeled cRNA was mixed and fragmented using the Agilent In Situ Hybridization Kit protocol (Agilent Technologies). Hybridization of cRNA targets was carried out on the Agilent human $22 \mathrm{~K} 60$-mer oligo microarray platform for $17 \mathrm{~h}$ at $60{ }^{\circ} \mathrm{C}$ in a rotating hybridization oven. Slides were washed according to the manufacturer's protocol and scanned with an Agilent Technologies DNA Microarray Scanner. Data were generated using the Agilent Feature Extraction software (version 7.5), employing defaults for all parameters. Two hybridizations, which include a fluor reversal, were performed for each RNA sample from each treatment group.

\section{Data analysis}

The goal of the microarray analysis was to characterize differences between the gene expression patterns in UROtsa cells that cannot methylate iAs and in UROtsa/F35 cells that are capable of iAs methylation before and after exposure to a subtoxic $(1 \mu \mathrm{M})$ or toxic $(50$ $\mu \mathrm{M})$ concentration of iAs ${ }^{\mathrm{III}}$. To achieve this goal, we first perform a rigorous statistical filter to find differentially expressed genes (DEGs) for each exposure group. A Venn analysis was then used to dissect out groups of genes associated with each condition. To identify affected pathways, these groups of genes were mapped to the MetaCore pathway database (GeneGo, (St. Joseph, MI) http://www.genego.com/). The MetaCore analysis identified functional links between differentially expressed genes associated with each condition. Results of this analysis were displayed in graphic form to answer the question: is there a pathway distribution more characteristic for one condition versus another?

Rosetta Resolver-Images and GEML (gene expression markup language) files, including error and $P$-values, were exported from the Agilent Feature Extraction software and uploaded into the Rosetta Resolver system (version 4.0, build 4.0.1.0.7.RSPLIT) (Rosetta Biosoftware, Kirkland, Washington, USA). We combined the resultant ratio 
profiles. Intensity plots were generated for each ratio experiment, and genes were considered "signature genes" if the $P$-value was $<0.001$. Data were analyzed using the Rosetta Resolver gene expression data analysis system (Rosetta Biosoftware). In Resolver, spots that are flagged during data acquisition by the Genepix software are not included in the analysis. In addition, if for a given spot intensities in both channels are below zero after background subtraction, the data are excluded from further analysis. Additional data processing in this system consists of error correction and calculation of a $P$-value of differential expression using the intensity-error estimation from the .gpr file. Error correction consists of a simplified version of the algorithm described by Schadt et al., ${ }^{14}$ in which a piecewise linear function replaces smoothing splines to fit and correct intensity non-linearity. Calculation of $P$-values consists of a statistic that combines additive and multiplicative error components in both channels of a two-colored experiment. The resultant ratio profiles (i.e., two-channel, error processed microarray scans) were combined into ratio experiments in the Resolver system as described in reference ${ }^{13}$. Within the Resolver system, we performed the analysis at the so-called sequence level. Specifically, when there are multiple data points for the same gene in the same hybridization, such data are combined. When combining data, it is assumed that the ratio measurement with the lowest overall error is closest to the true value for that sequence, and weights are constructed such that the feature or reporter with the lowest error is given the greatest weight. ${ }^{14}$

MetaCore GENEGO analysis-We further analyzed the signature genes with MetaCore GeneGO Systems Biology Analysis Software ${ }^{\circledR}$, a web-delivered application that enables biologists to discover, visualize, and explore relevant networks significant to their experimental results, such as gene expression array data sets. A data set containing gene identifiers and their corresponding expression values such as fold-changes and $P$-values was uploaded as a tab-delimited text file. Each gene identifier was mapped to its corresponding gene object in the MetaCore ${ }^{\circledR}$ Knowledge Base. A fold change cutoff of 1.5 -fold and $P<$ 0.001 was set to identify genes whose expression was differentially regulated. These genes, called "focus genes," were then used as the starting point for generating biological networks. To start building networks, the application queries the Ingenuity Pathways Knowledge Base for interactions between focus genes and all other gene objects stored in the knowledge base, and then generates a set of maps and networks. For significance, a hypergeometric distribution is used to compute a map or network $P$-value, the number of genes for each map as well as the numbers of genes in your submitted list, and a percentage for the map. The score is derived from a $P$-value and indicates the likelihood of the genes in a network being found together because of random chance. Other pathway mapping softwares were used to visualize significant pathways including DAVID/EASE (http://david.niaid.nih.gov/david/ ease.htm) and Ingenuity@ Pathway Analysis (Mountain View, California, USA; http:// www.ingenuity.com/index.html).

DAVID Bioinformatic Resources 2006-Using a gene list derived from Venn analysis, we mapped genes passing the filter to DAVID Functional analysis (National Institute of Allergy and Infectious Diseases; http://david.abcc.ncifcrf.gov/gene2gene.jsp) to classify the genes on this list into functional related gene groups.

Statistics-For the Metacore GeneGO Analysis, we used a Fisher's exact test to calculate a $P$-value to determine the probability that the biological function assigned to that network could be explained by chance alone. The level of significance was set at $P<0.05$ in all cases. 


\section{Results}

\section{Metabolic characteristics of UROtsa and Urotsa/F35 cells}

iAs was the only As species detected in cell lysates and media from UROtsa cultures exposed for $24 \mathrm{~h}$ to 1 or $50 \mu \mathrm{M}\left[{ }^{73} \mathrm{As}\right] \mathrm{iAs}{ }^{\mathrm{III}}$ (Figures 1 and 2); cells contained $4 \%$ and $8 \%$ of total ${ }^{73} \mathrm{As}$ in culture, respectively. In contrast, UROtsa/F35 cells methylated $\left[{ }^{73} \mathrm{As}\right] \mathrm{iAs}{ }^{\mathrm{III}}$ to radiolabeled MAs and DMAs. In UROtsa/F35 cultures exposed to $1 \mu \mathrm{M}\left[{ }^{73} \mathrm{As}\right] \mathrm{iAs}{ }^{\mathrm{III}}$, MAs and DMAs accounted for $3 \%$ and $73 \%$ of ${ }^{73} \mathrm{As}$ retained in cells and for $<0.1 \%$ and $25 \%$ of ${ }^{73} \mathrm{As}$ in medium. In UROtsa/F35 cultures exposed to $50 \mu \mathrm{M}\left[{ }^{73} \mathrm{As}\right] \mathrm{iAs}{ }^{\mathrm{III}}$, MAs was the major methylated metabolite representing $28 \%$ of ${ }^{73} \mathrm{As}$ retained in cells and $14 \%$ of ${ }^{73} \mathrm{As}$ in medium. In UROtsa/F35 cultures exposed to 1 and $50 \mu \mathrm{M}\left[{ }^{73} \mathrm{As}\right] \mathrm{iAs}{ }^{\mathrm{III}}$, cells contained $9 \%$ and $6 \%$ of total ${ }^{73} \mathrm{As}$, respectively.

\section{Principal component and Venn analyses}

Principal component analysis was performed to capture the variability in gene expression space by reducing the high dimensionality of the expression data to two or three components. Results are shown in Figure 3. At $1 \mu \mathrm{M}$ iAs ${ }^{\mathrm{III}}$ exposure level, UROtsa/F35 cells and UROtsa cells showed similarity to each other. However these cells exposed to 1 $\mu \mathrm{M} A s^{\mathrm{III}}$ differ significantly from cells exposed to $50 \mu \mathrm{M}$ iAs ${ }^{\mathrm{III}}$. In contrast, at the $50 \mu \mathrm{M}$ iAs ${ }^{\mathrm{III}}$ exposure, UROtsa/F35 cells were distinct from the UROtsa cells. Gene lists were generated in Rosetta Resolver for each condition, including UROtsa/F35 cells at $1 \mu \mathrm{M}$ or 50 $\mu \mathrm{M}$ iAs ${ }^{\mathrm{III}}$, and UROtsa cells at $1 \mu \mathrm{M}$ or $50 \mu \mathrm{M}$ iAs ${ }^{\mathrm{III}}$. Venn analysis (figures $4 \mathrm{~A}$ and $4 \mathrm{~B}$ ) showed that exposure to $1 \mu \mathrm{M}$ iAs ${ }^{I I I}$ uniquely altered expression of 96 genes in UROtsa cells, but only 24 genes in methylating Urotsa/F35 cells. Fourteen genes were altered in both cell lines. In contrast, exposure to $50 \mu \mathrm{M}$ iAs ${ }^{\mathrm{III}}$ had a greater impact on gene expression in Urotsa/F35 cells, changing uniquely expression of 1389 genes as compared to 649 genes in UROtsa. Changes in expression of 5033 genes were shared by both cell lines.

\section{Cell line-specific pathway effects at 1 and $50 \mu \mathrm{M}$ iAs ${ }^{\prime \prime I}$}

Venn analysis gene lists were mapped to evaluate effects of the exposures on specific pathways. Table 1a shows that, in UROtsa cells exposed to the subtoxic concentration of 1 $\mu \mathrm{M}$ iAs ${ }^{\mathrm{III}}$, affected mainly pathways regulating cell adhesion and carbohydrate metabolism. In comparison, pathways regulating cell cycle were altered in UROtsa/F35 cells at this exposure level (Table 1b). In general, the number of pathways affected by exposure to $1 \mu \mathrm{M}$ iAs ${ }^{I I I}$ was relatively small (5-7) for either cell line. In contrast, the number of pathways altered by the cytotoxic concentration of $50 \mu \mathrm{M} \mathrm{iAs}{ }^{\mathrm{III}}$ was significantly greater: 12 in UROtsa and 37 in UROtsa/F35 cells (Table 2a,b). UROtsa and UROtsa/F35 exposed to 50 $\mu \mathrm{M}$ iAs ${ }^{\mathrm{III}}$ shared some similarity in functional gene categories including cell death, transcription, and kinases; however, there were no common pathways altered in both cell lines. Pathways altered in UROtsa cells were characterized by the following categories: cell cycle, cell death, regulation of transcription, and metabolic pathways. Pathways altered in the UROtsa/F35 cells involved cell adhesion, cell death, growth and differentiation, immune response, transcription, G-protein signaling, and metabolism.

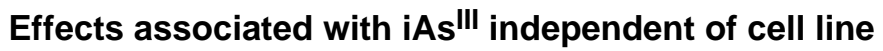

The Venn unions for the exposures to $1 \mu \mathrm{M}$ iAs ${ }^{\mathrm{III}}$ (Figure 4A) and $50 \mu \mathrm{M}$ iAs ${ }^{\mathrm{III}}$ (Figure 4B) contained 14 and 5033 genes, respectively. These gene lists were mapped to identify which pathway changes were specifically associated with the iAs ${ }^{\mathrm{III}}$ exposure. Exposure to $1 \mu \mathrm{M}$ iAs ${ }^{\mathrm{III}}$ had a minimal effect, affecting only 10 pathways with only a few genes altered per pathway (Table 3a). Cell adhesion, growth and differentiation, and metabolism were the affected gene categories. However, exposure to $50 \mu \mathrm{M}$ iAs ${ }^{\text {III }}$ produced a marked increase in 
number of altered pathways with the percentage of pathway coverage ranging from 26 to $78 \%$ of genes (Table $3 \mathrm{~b}$ ). The pathways involved in cell cycle regulation and cell death and apoptosis were among the most affected. Notably, some of altered gene categories were similar for both exposure levels. However, at $50 \mu \mathrm{M}$ iAs ${ }^{\mathrm{III}}$ the numbers of altered pathways within each gene category (e.g., cycle control, growth and death, or nucleotide metabolism) were much greater than at $1 \mu \mathrm{M}$ level.

\section{Changes in pathway distribution}

The 10 most significantly altered pathways for each experimental condition (Tables 1 and 2) were categorized by function. Results were displayed graphically to assess whether there was a characteristic distribution signature of significantly altered pathways associated with each condition, including UROtsa-50 $\mu \mathrm{M}$ iAs ${ }^{\mathrm{III}}$, UROtsa/F35-50 $\mu \mathrm{M}$ iAs ${ }^{\mathrm{III}}$, UROtsa-1 $\mu \mathrm{M}$ iAs ${ }^{\mathrm{III}}$, and UROtsa/F35-1 $\mu \mathrm{M}$ iAs ${ }^{\mathrm{III}}$ (Figure 5). Changes in the pathways regulating metabolism and cell adhesion were characteristic for UROtsa cells exposed to $1 \mu \mathrm{M}$ iAs ${ }^{\mathrm{III}}$. Changes in the pathways associated with cell cycle regulation were unique for UROtsa/F35 cells at this exposure level. The exposure of UROtsa cells to $50 \mu \mathrm{M}$ iAs ${ }^{\mathrm{III}}$ was characterized by major effects on pathways regulating metabolism, followed by pathways associated with transcription, cell death, and cell cycle. Pathways regulating metabolism and cell deaths were also affected in UROtsa/F35 cells exposed to $50 \mu \mathrm{M}$ iAs ${ }^{\mathrm{III}}$. However, alterations in pathways involved in cell growth, signaling, and cell adhesion were unique for this cell line under these exposure conditions.

\section{Strain effects on functional gene categories}

Further analyses focused only on effects of the sub-toxic exposure to $1 \mu \mathrm{M}$ iAs ${ }^{\mathrm{III}}$, as this concentration is relevant for chronic environmental exposures to iAs. We utilized the Venn analysis displayed in Figure 4A to identify genes uniquely associated with UROtsa (96 genes) or UROtsa/F35 cells ( 24 genes) exposed to $1 \mu \mathrm{M}$ iAs. Mapping such small numbers of genes to pathways did not yield meaningful results. Therefore, we focused on examination of functional clusters of genes contained within these lists. We mapped the gene lists to DAVID Bioinformatic software to find any highly related genes and their annotations to understand the common biology among related genes. The results are presented in Table $4 \mathrm{a}, \mathrm{b}$ and Figures $6 \mathrm{~A}$ and $6 \mathrm{~B}$. The functional clusters of genes associated with methylating UROtsa/F35 exposed to $1 \mu \mathrm{M}$ iAs (Figure 6A) are involved in chromosome stability, DNA synthesis, and cell cycle as compared to non-methylating UROtsa cells (Figure 6B) that showed a gene cluster of metallothioneins, proteins with a high content of cysteine residues that bind various heavy metals.

\section{Discussion}

It has been generally recognized that the enzymatic methylation of iAs is one of the key factors that determine outcomes of acute and chronic exposures to iAs. Methylated arsenicals containing $\mathrm{As}^{\mathrm{III}}$ (MAs ${ }^{\mathrm{III}}$ and DMAs ${ }^{\mathrm{III}}$ ) are more toxic than iAs species in animal and cell culture models $\mathrm{s}^{8,15,16}$ and are more potent than iAs as genotoxins, inhibitors of several redox enzymes, and modulators of major signal transduction pathways in mammalian cells. ${ }^{7,17,18}$ At low sub-micromolar levels, both iAs ${ }^{\mathrm{III}}$ and methylated trivalent arsenicals induce production of inflammatory and growth promoting cytokines and cell proliferation. ${ }^{19}$ Chronic exposures to low micromolar concentrations of iAs ${ }^{\mathrm{III}}$ have been shown to induce malignant transformation in human cells that lack As methylation activity, ${ }^{20}$ indicating that methylation is not required for iAs to produce malignant phenotype. However, recent studies showed that in UROtsa cultures, malignant transformation can be induced by either iAs ${ }^{\mathrm{III}}$ or MAs ${ }^{\mathrm{III}}$. Notably, the concentration that 
transformed UROtsa cells to malignant phenotype was much lower for MAs ${ }^{\mathrm{III}}(0.05 \mu \mathrm{M})^{21}$ as compared to iAs ${ }^{\mathrm{III}}(1 \mu \mathrm{M}) .^{22}$

Changes in gene expression associated with exposures to iAs have been extensively studied in both animal and cell culture models. However, little is known about the role of methylation in modulation of the effects of iAs exposure on gene expression. Su and associates $^{23}$ have recently examined gene expression profiles in non-tumorigenic SV-40transformed human urothelial (HUC-1) cells chronically exposed to iAs ${ }^{\mathrm{III}}$, MAs ${ }^{\mathrm{III}}$, or

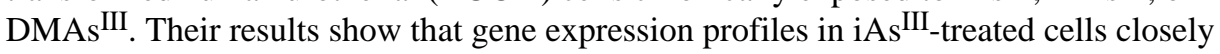
resemble those found in tumorigenic HUC-1 cells generated by treatment with methylcholanthrene. Notably, effects of MAs ${ }^{\mathrm{III}}$, and particularly of DMAs ${ }^{\mathrm{III}}$, on gene expression differed significantly from the effects of $\mathrm{iAs}^{\mathrm{III}}$. In our study, effects of iAs ${ }^{\mathrm{III}}$ on gene expression pattern were examined in UROtsa cells that lack As methylation activity and in UROtsa/F35 cells that acquired this activity after stable expression of AS3MT. Thus, instead of examining the effects of individual arsenicals, this study evaluates effects of a mixture of natural metabolites of iAs produced by the AS3MT-catalyzed reactions and distributed between the cells and the extracellular compartment in a manner that may be consistent with in vivo processes in tissues methylating iAs or tissues that do not express AS3MT, but are exposed to methylated metabolites produced elsewhere.

In this study, we chose to examine effects of two iAs ${ }^{\mathrm{III}}$ concentrations: 1 and $50 \mu \mathrm{M}$. The metabolism and cytotoxicity of iAs ${ }^{\mathrm{III}}$ in UROtsa and UROtsa/F35 cultures exposed to these concentrations have been characterized in details in our previous report. ${ }^{11}$ Briefly, we have shown that a 24-h exposure to $1 \mu \mathrm{M}$ iAs ${ }^{\mathrm{III}}$ had no effect on viability of either UROtsa or UROtsa/F35 cells. In contrast, exposure to $50 \mu \mathrm{M}$ iAs ${ }^{\mathrm{III}}$ decreased viability of UROtsa or UROtsa/F35 cells by about 10 and $30 \%$, respectively. Therefore, we refer to $1 \mu \mathrm{M}$ iAs ${ }^{\mathrm{III}}$ as the "non-toxic" or "subtoxic" concentration and $50 \mu \mathrm{M}$ iAs $\mathrm{III}$ as the "cytotoxic" concentration. Results of this study suggest that gene expression profiles in cells exposed to iAs ${ }^{\mathrm{III}}$ depend strongly on the concentration of iAs ${ }^{\mathrm{III}}$ in culture and on the presence of AS3MT activity. Consistent with these findings, the exposure to the cytotoxic concentration of $50 \mu \mathrm{M}$ iAs ${ }^{\text {III }}$ produced far more extensive changes in gene expression pattern than exposure to the subtoxic concentration of $1 \mu \mathrm{M}$ iAs ${ }^{\mathrm{III}}$. Given the numbers of genes affected, the effects of the subtoxic concentration of $1 \mu \mathrm{M}$ iAs ${ }^{\mathrm{III}}$ were less pronounced in methylating UROtsa/F35 as compared to parent UROtsa cells (Figure 4). Under these conditions, iAs ${ }^{\text {III }}$ was effectively methylated, yielding almost exclusively DMAs (Figure 1). Thus, at this exposure level, the efficient conversion of iAs ${ }^{\mathrm{III}}$ to DMAs might play a detoxification role, limiting the immediate effects of iAs ${ }^{\mathrm{III}}$ and particularly effects of the highly reactive intermediary metabolite, MAs ${ }^{\mathrm{III}}$, on gene expression. Notably, significant changes in expression of genes regulating cell cycle in UROtsa/F35 cells exposed to $1 \mu \mathrm{M}$ iAs ${ }^{\mathrm{III}}$ (Figure 5A) are consistent with previously reported proliferative effects of low, submicromolar concentrations of trivalent arsenicals, specifically MAs ${ }^{\mathrm{III}}$ and DMAs ${ }^{\mathrm{III}} .{ }^{19}$

In general, 24-h exposures to $1 \mu \mathrm{M}$ iAs ${ }^{\mathrm{III}}$ had little effect on gene expression pattern and pathways in either parent UROtsa or UROtsa/F35 cells. However, examination of potential functional clusters of genes revealed specific responses associated with the presence or absence of AS3MT activity. Exposure to $1 \mu \mathrm{M}$ iAs ${ }^{\mathrm{III}}$ significantly altered a cluster of genes involved in chromosomal stability, DNA synthesis, and cell cycle in methylating UROtsa/ F35 cells (Figure 6). These alterations are consistent with malignant transformation of UROtsa cells by chronic exposures to very low concentrations of MAs ${ }^{\mathrm{III}}$ described by Bredfeldt and associates. ${ }^{21}$ In contrast, in non-methylating UROtsa cells, exposure to $1 \mu \mathrm{M}$ iAs ${ }^{\mathrm{III}}$ affected a cluster of genes regulating expression of metallothioneins (Figure 6B). Zhou and associates have shown that malignant transformation of UROtsa cells by exposure to iAs is associated with an increased expression of metallothionein. ${ }^{24}$ Binding of iAs to 
cysteine-rich domains in the molecule of metallothionin is thought to contribute to detoxification of iAs in mammalian cells. ${ }^{25,26}$ Effects of methylated metabolites of iAs on metallothionein expression or effects of metallothionein on toxicity of methylated arsenicals have not been examined.

Unlike the exposure to subtoxic $1 \mu \mathrm{M}$ iAs ${ }^{\mathrm{III}}$, exposure to cytotoxic $50 \mu \mathrm{M}$ iAs ${ }^{\mathrm{III}}$ has more pronounced effects on methylating cells; twice as many genes in UROtsa/F35 were affected as compared to UROtsa cells (Figure 3B). Consistent with previous reports, ${ }^{5,27}$ high concentration of iAs ${ }^{\mathrm{III}}$ in UROtsa/F35 culture inhibited As methylation activity, specifically DMAs formation; MAs was the major methylated metabolite found both in cells and culture medium (Figure 2). Thus, the pronounced effects of $50 \mu \mathrm{M}$ iAs ${ }^{\mathrm{III}}$ in UROtsa/F35 cells, particularly the specific effects on genes associated with cell adhesion, cell growth, and signaling (Figure 5B) can be at least in part attributed to MAs production. These data are in a good agreement with results of our previous study that linked the increased susceptibility of UROtsa/F35 cells to acute toxicity of iAs with formation and accumulation of MAs, specifically MAs ${ }^{\mathrm{III}} .{ }^{11}$ Taken together, accumulation of MAs ${ }^{\mathrm{III}}$ and the MAs ${ }^{\mathrm{III}}$-induced changes in gene expression may contribute in a significant way to toxicity of acute exposures to high concentrations/doses of iAs that inhibit AS3MT-catalyzed production of DMAs, thus impairing the capacity of cells to detoxify iAs. However, it is possible that high concentrations of iAs in tissues may also result from chronic environmental or occupation exposures to high levels of iAs in environmental media, particularly, in individuals with impaired capacity to methylate iAs due to liver disease or due to AS3MT polymorphisms that favor MAs production.

In summary, results of the present study provide additional evidence for an important role of AS3MT-catalyzed methylation in modulation of iAs toxicity. More research will be needed to dissect the effects of iAs exposure on specific clusters of genes and pathways in methylating cells and in cells lacking the As methylation activity and to link these effects to specific toxicities associated with acute and chronic exposures to iAs.

\section{Acknowledgments}

The research described in this article has been reviewed by the National Health and Environmental Effects Research Laboratory, US Environmental Protection Agency, and approved for publication. Approval does not signify that the contents necessarily reflect the views and the policies of the Agency, nor does mention of trade names or commercial products constitute endorsement or recommendation for use. The authors wish to thank $\operatorname{Dr}$ Ram Ramabhadran and Dr Kirk Kitchin for review of this manuscript. The work was supported [in part] by the Intramural Research Program of the NIH, National Cancer Institute, Center for Cancer Research.

\section{References}

1. Thomas DJ, Li J, Waters SB, Xing W, Adair BM, Drobna Z, Devesa V. Arsenic (+3 oxidation state) methyltransferase and the methylation of arsenicals. Exp Biol Med (Maywood). 2007; 232:3-13. [PubMed: 17202581]

2. Thomas DJ, Waters SB, Styblo M. Elucidating the pathway for arsenic methylation. Toxicol Appl Pharmacol. 2004; 198:319-326. [PubMed: 15276411]

3. Li J, Waters SB, Drobna Z, Devesa V, Styblo M, Thomas DJ. Arsenic (+3 oxidation state) methyltransferase and the inorganic arsenic methylation phenotype. Toxicol Appl Pharmacol. 2005; 204:164-169. [PubMed: 15808521]

4. Lin S, Shi Q, Nix FB, Styblo M, Beck MA, Herbin-Davis KM, et al. A novel S-adenosyl-Lmethionine: arsenic(III) methyltransferase from rat liver cytosol. J Biol Chem. 2002; 277:1079510803. [PubMed: 11790780]

5. Devesa V, Del Razo LM, Adair B, Drobná Z, Waters SB, Hughes MF, et al. Comprehensive analysis of arsenic metabolites by $\mathrm{pH}$-specific hydride generation atomic absorption spectrometry. $\mathrm{J}$ Anal At Spectrom. 2004; 19:1460-1467. 
6. Hernandez-Zavala A, Matoušek T, Drobná Z, Adair BM, Dědina J, Thomas DJ, et al. Speciation of arsenic in biological matrices by automated hydride gneration-cryotrapping-atomic absorption spectrometry with multiple microflame quartz tube atomizer (multiatomizer). J Anal At Spectom. 2008:23.

7. Thomas DJ, Styblo M, Lin S. The cellular metabolism and systemic toxicity of arsenic. Toxicol Appl Pharmacol. 2001; 176:127-144. [PubMed: 11601889]

8. Styblo M, Drobná Z, Jaspers I, Lin S, Thomas DJ. The role of biomethylation in toxicity and carcinogenicity of arsenic: a research update. Environ Health Perspect. 2002; 110(Suppl 5):767771. [PubMed: 12426129]

9. Petrick JS, Jagadish B, Mash EA, Aposhian HV. Monomethylarsonous acid (MMA(III)) and arsenite: $\mathrm{LD}(50)$ in hamsters and in vitro inhibition of pyruvate dehydrogenase. Chem Res Toxicol. 2001; 14:651-656. [PubMed: 11409934]

10. Drobná Z, Waters SB, Walton FS, LeCluyse EL, Thomas DJ, Styblo M. Interindividual variation in the metabolism of arsenic in cultured primary human hepatocytes. Toxicol Appl Pharmacol. 2004; 201:166-177. [PubMed: 15541756]

11. Drobná Z, Waters SB, Devesa V, Harmon AW, Thomas DJ, Stýblo M. Metabolism and toxicity of arsenic in human urothelial cells expressing rat arsenic ( +3 oxidation state)-methyltransferase. Toxicol Appl Pharmacol. 2005; 207:147-159. [PubMed: 16102566]

12. Styblo M, Yamauchi H, Thomas DJ. Comparative in vitro methylation of trivalent and pentavalent arsenicals. Toxicol Appl Pharmacol. 1995; 135:172-178. [PubMed: 8545824]

13. Dai H, Meyer M, Stepaniants S, Ziman M, Stoughton R. Use of hybridization kinetics for differentiating specific from non-specific binding to oligonucleotide microarrays. Nucleic Acids Res. 2002; 30:e86. [PubMed: 12177314]

14. Schadt EE, Li C, Ellis B, Wong WH. Feature extraction and normalization algorithms for highdensity oligonucleotide gene expression array data. J Cell Biochem Suppl. 2001; (Suppl 37):120 125. [PubMed: 11842437]

15. Styblo M, Del Razo LM, Vega L, Germolec DR, LeCluyse EL, Hamilton GA. Comparative toxicity of trivalent and pentavalent inorganic and methylated arsenicals in rat and human cells. Arch Toxicol. 2000; 74:289-299. [PubMed: 11005674]

16. Petrick JS, Ayala-Fierro F, Cullen WR, Carter DE. Monomethylarsonous acid (MMA(III)) is more toxic than arsenite in Chang human hepatocytes. Toxicol Appl Pharmacol. 2000; 163:203-207. [PubMed: 10698679]

17. Drobna Z, Jaspers I, Thomas DJ, Styblo M. Differential activation of AP-1 in human bladder epithelial cells by inorganic and methylated arsenicals. FASEB J. 2003; 17:67-69. [PubMed: 12475910]

18. Paul DS, et al. Molecular mechanisms of the diabetogenic effects of arsenic: inhibition of insulin signaling by arsenite and methylarsonous acid. Environ Health Perspect. 2007; 115:734-742. [PubMed: 17520061]

19. Vega L, Styblo M, Patterson R, Cullen W, Wang C, Germolec D. Differential effects of trivalent and pentavalent arsenicals on cell proliferation and cytokine secretion in normal human epidermal keratinocytes. Toxicol Appl Pharmacol. 2001; 172:225-232. [PubMed: 11312651]

20. Benbrahim-Tallaa L, Waterland RA, Styblo M, Achanzar WE, Webber MM, Waalkes MP. Molecular events associated with arsenic-induced malignant transformation of human prostatic epithelial cells: aberrant genomic DNA methylation and K-ras oncogene activation. Toxicol Appl Pharmacol. 2005; 206:288-298. [PubMed: 16039940]

21. Bredfeldt TG, Jagadish B, Eblin KE, Mash EA, Gandolfi AJ. Monomethylarsonous acid induces transformation of human bladder cells. Toxicol Appl Pharmacol. 2006; 216:69-79. [PubMed: 16806342]

22. Sens DA, Park S, Gurel V, Sens MA, Garrett SH, Somji S. Inorganic cadmium- and arseniteinduced malignant transformation of human bladder urothelial cells. Toxicol Sci. 2004; 79:56-63. [PubMed: 14976345]

23. Su PF, Hu YJ, Ho IC, Cheng YM, Lee TC. Distinct gene expression profiles in immortalized human urothelial cells exposed to inorganic arsenite and its methylated trivalent metabolites. Environ Health Perspect. 2006; 114:394-403. [PubMed: 16507463] 
24. Zhou XD, Sens DA, Sens MA, Namburi VB, Singh RK, Garrett SH, et al. Metallothionein-1 and -2 expression in cadmium- or arsenic-derived human malignant urothelial cells and tumor heterotransplants and as a prognostic indicator in human bladder cancer. Toxicol Sci. 2006; 91:467-475. [PubMed: 16565513]

25. Zhou P, Kalakonda N, Comenzo RL. Changes in gene expression profiles of multiple myeloma cells induced by arsenic trioxide (ATO): possible mechanisms to explain ATO resistance in vivo. Br J Haematol. 2005; 128:636-644. [PubMed: 15725085]

26. Peng Z, Peng L, Fan Y, Zandi E, Shertzer HG, Xia Y. A critical role for IkappaB kinase beta in metallothionein-1 expression and protection against arsenic toxicity. J Biol Chem. 2007; 282:21487-21496. [PubMed: 17526490]

27. Styblo M, Del Razo LM, LeCluyse EL, Hamilton GA, Wang C, Cullen WR, et al. Metabolism of arsenic in primary cultures of human and rat hepatocytes. Chem Res Toxicol. 1999; 12:560-565. [PubMed: 10409394] 

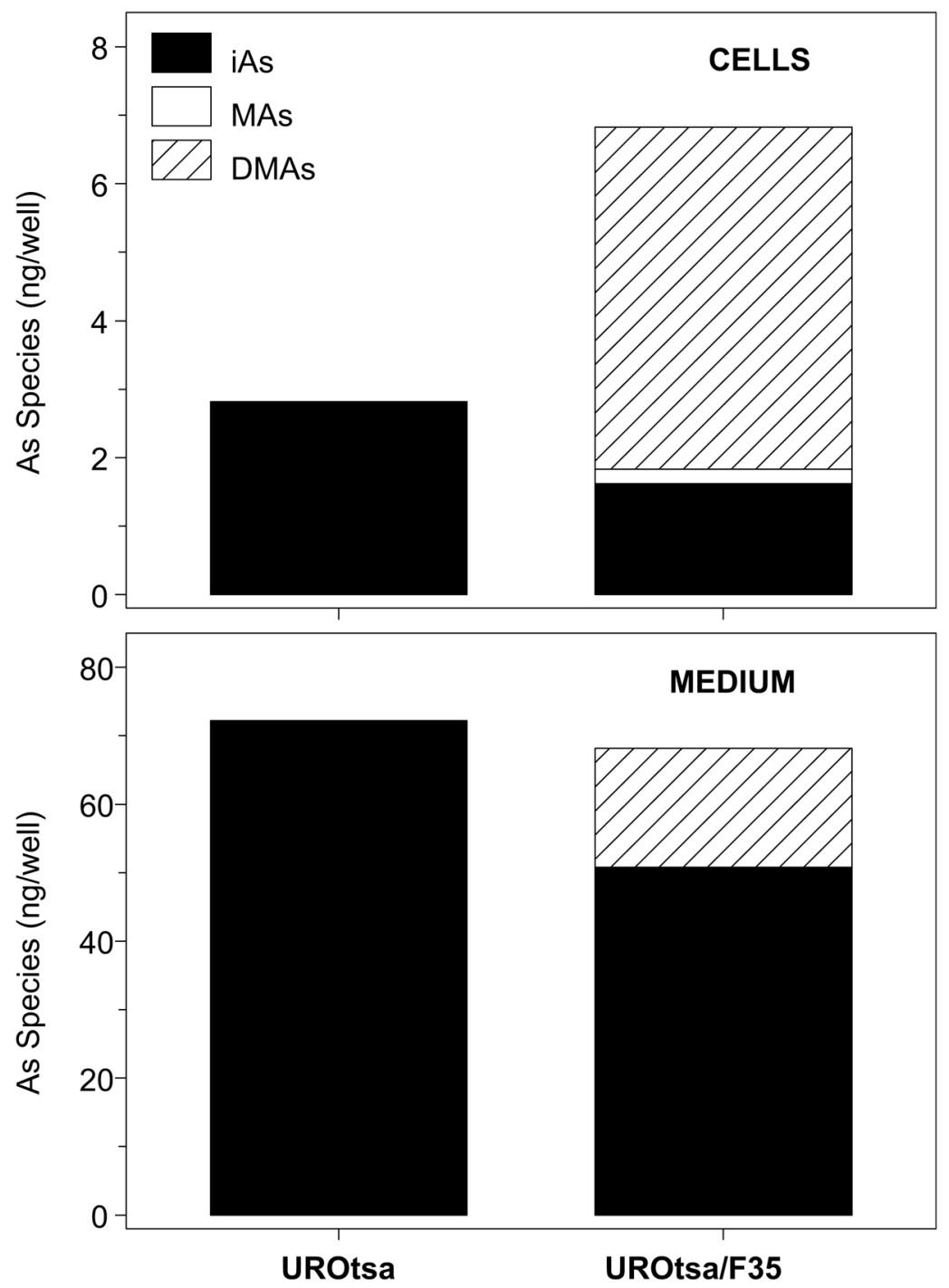

Figure 1.

Distribution of As species in UROtsa and UROtsa/F35 cultures exposed to $1 \mu \mathrm{M}$ $\left[{ }^{73} \mathrm{As}\right] \mathrm{iAs}{ }^{\mathrm{III}}$ for $24 \mathrm{~h}$. The average concentrations of iAs, MAs, and DMAs are shown for $n=$ 3. 

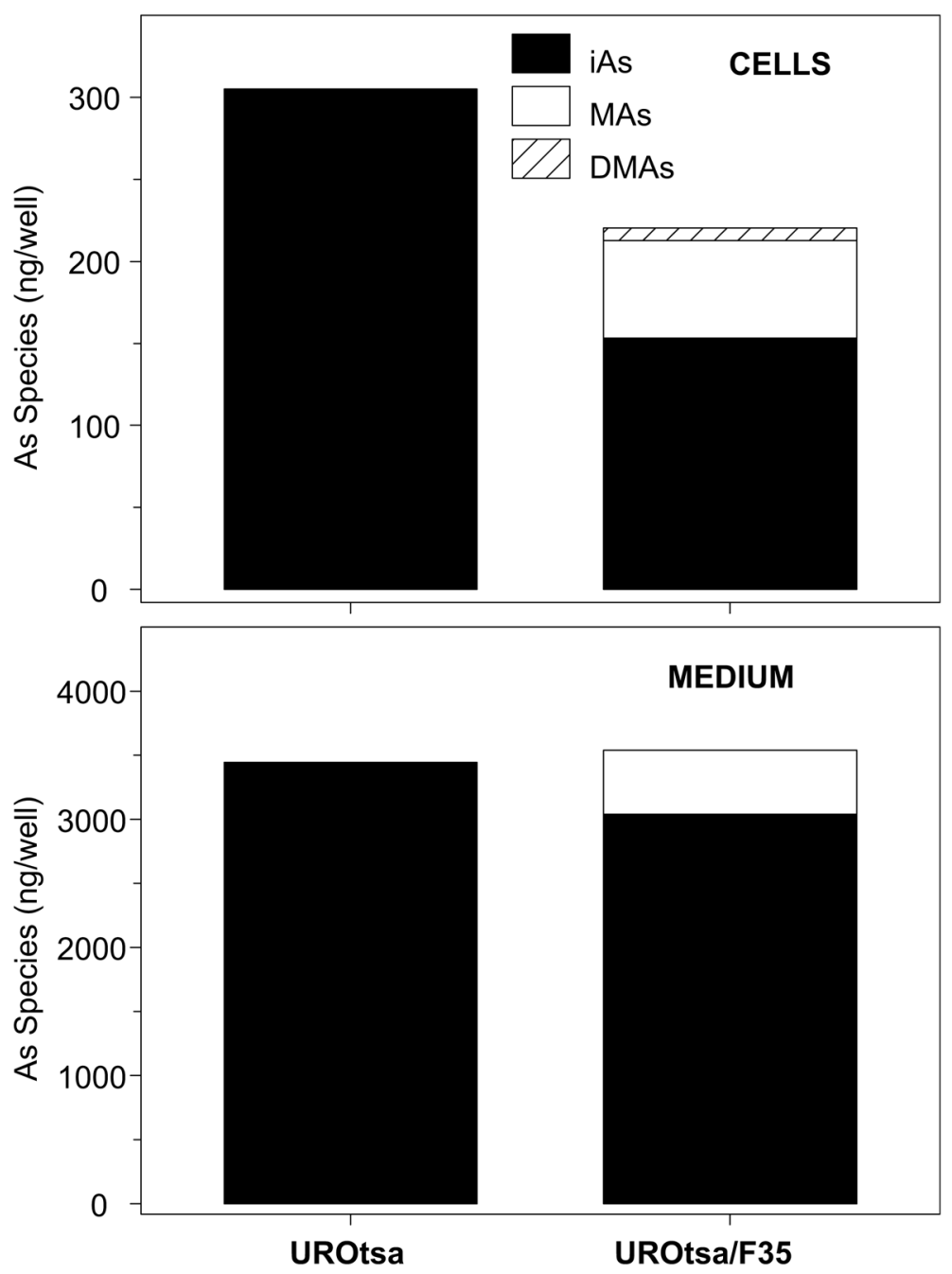

Figure 2.

Distribution of As species in UROtsa and UROtsa/F35 cultures exposed to $50 \mu \mathrm{M}$ $\left[{ }^{73} \mathrm{As}\right] \mathrm{iAs}{ }^{\mathrm{III}}$ for $24 \mathrm{~h}$. The average concentrations of iAs, MAs, and DMAs are shown for $n=$ 3. 


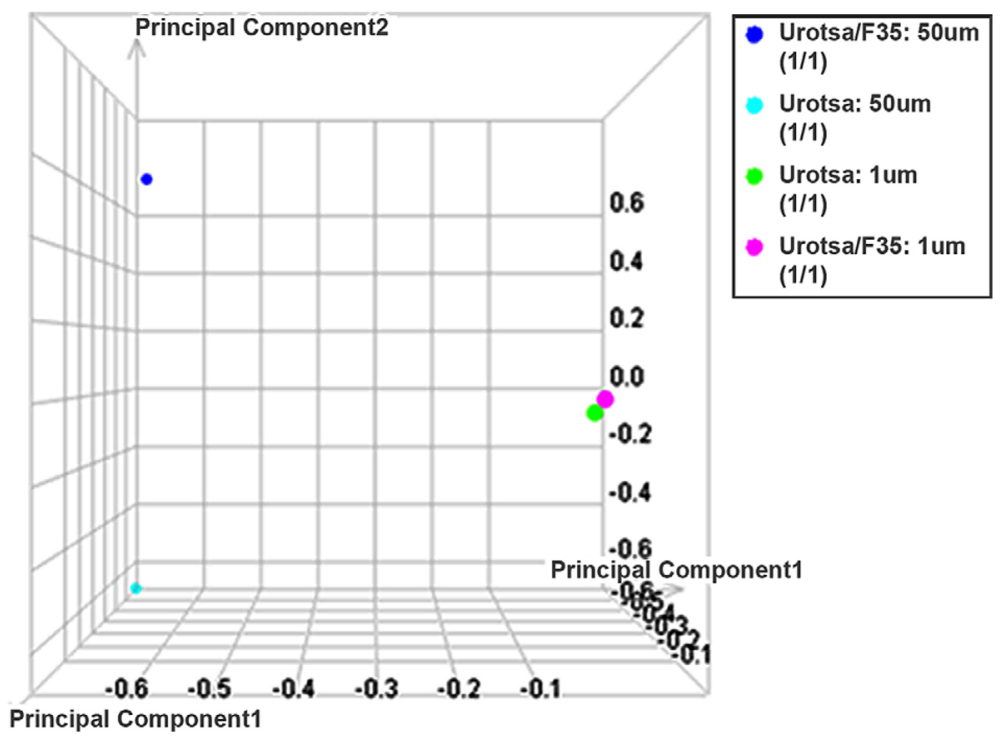

Figure 3.

Results of the principal component analysis of variability of gene expression in UROtsa and UROtsa/35 cells before and after exposure to 1 or $50 \mu \mathrm{M}$ iAs ${ }^{\text {III }}$. 
A

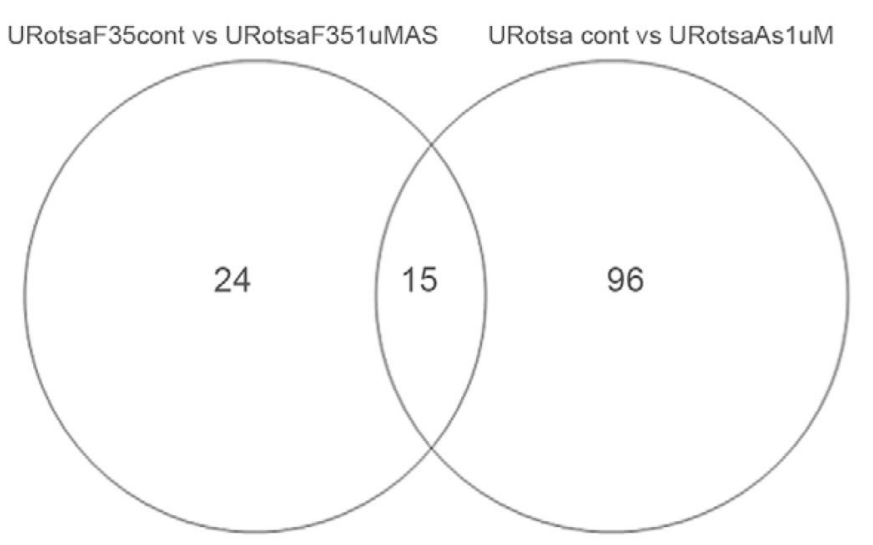

B
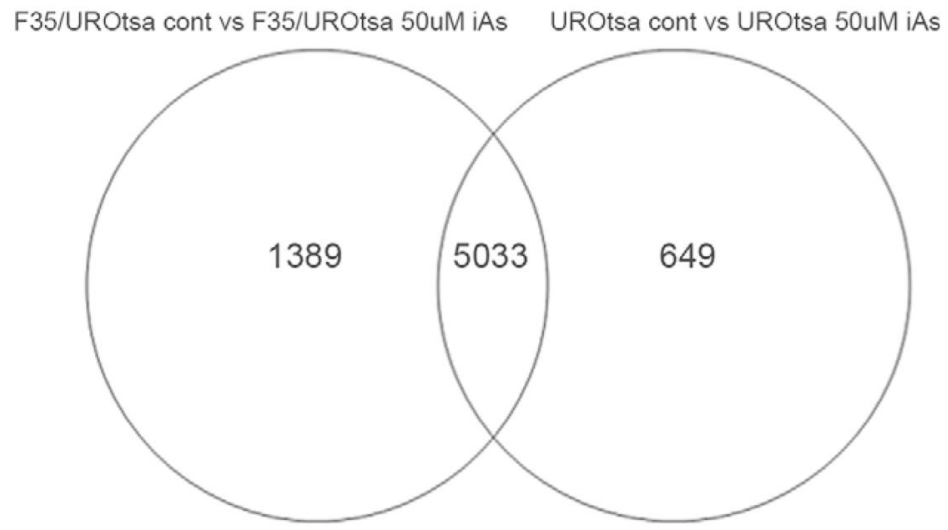

Figure 4.

Venn analysis of statistically filtered genes in UROtsa and UROtsa/F35 cells exposed to 1 $\mu \mathrm{M}$ iAs ${ }^{\mathrm{III}}$ (A) and $50 \mu \mathrm{M}$ iAs ${ }^{\mathrm{III}}$ (B). 

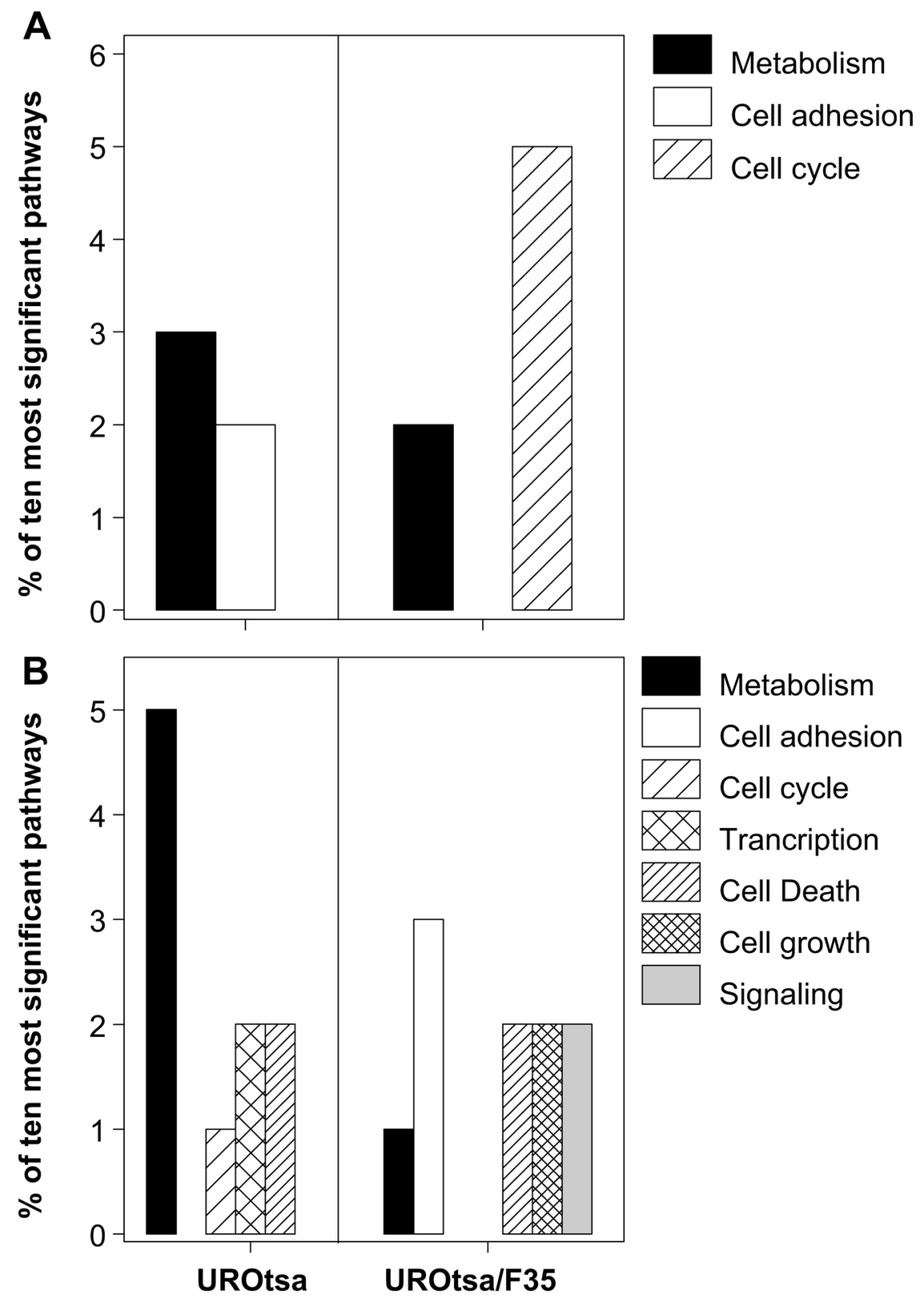

Figure 5.

Changes in pathway distribution in UROtsa and UROtsa/F35 cells. The pathways most significantly affected by exposures to $1 \mu \mathrm{M}$ iAs ${ }^{\mathrm{III}}$ (A) and $50 \mu \mathrm{M}$ iAs ${ }^{\mathrm{III}}$ (B). 


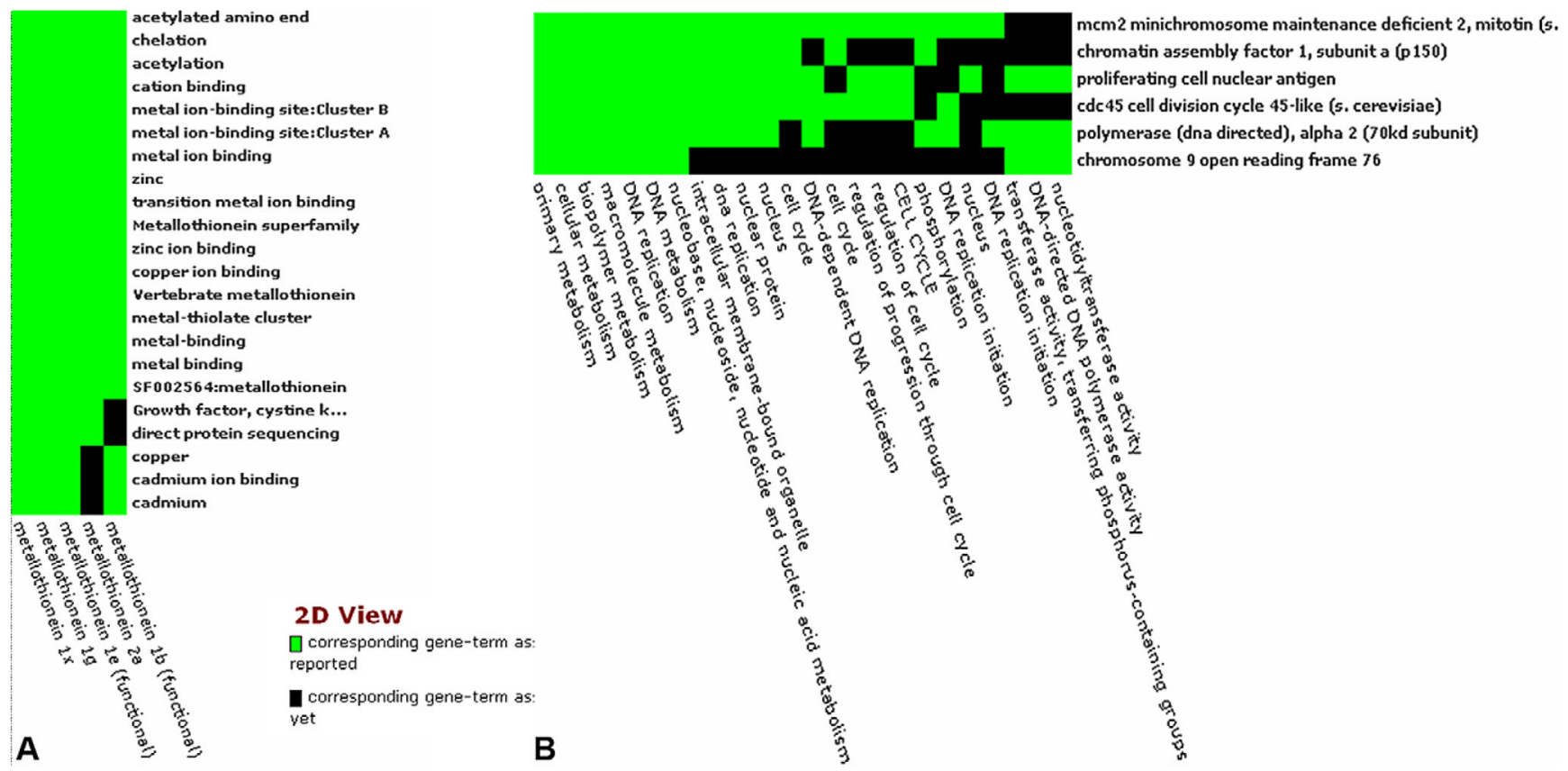

Figure 6.

Gene clusters uniquely associated with UROtsa cells (A) and UROtsa/F35 cells (B) exposed to $1 \mu \mathrm{M}$ iAs ${ }^{\text {III }}$. 
Table 1a

Effects of UROtsa genotype exposed to $1 \mu \mathrm{M}$ iAs at the pathway level

\begin{tabular}{lllrr}
\hline Pathway & $\boldsymbol{P}$-Value & No. of genes expressed & No. of genes in pathway & Percentage $(\%)$ \\
\hline Cell adhesion & & & & \\
$\quad$ ECM remodeling & $4.44 \mathrm{E}-05$ & 5 & 60 & 8 \\
$\quad$ Chemokines and adhesion & $4.88 \mathrm{E}-02$ & 4 & 209 & 2 \\
Carbohydrate metabolism & & & 15 & 13 \\
$\quad \begin{array}{l}\text { Pentose phosphate pathway } \\
\text { Glycolysis and gluconeogenesis p. 1 }\end{array}$ & $4.25 \mathrm{E}-03$ & 2 & 19 & 11 \\
$\quad$ Fructose metabolism & $1.76 \mathrm{E}-03$ & 2 & 31 & 6 \\
\hline
\end{tabular}




\section{Table 1b}

Effects of UROtsa/F35 genotype exposed to $1 \mu \mathrm{M}$ iAs at the pathway level

\begin{tabular}{lllll}
\hline Pathway & $\boldsymbol{P}$-Value & No. of genes expressed & No. of genes in pathway & Percentage (\%) \\
\hline Cell cycle control & & & & \\
Start of DNA replication in early S phase & $1.12 \mathrm{E}-06$ & 4 & 43 & 9 \\
Transition and termination of DNA replication & $4.03 \mathrm{E}-05$ & 3 & 36 & 8 \\
ATM/ATR regulation of G1/S checkpoint & $2.82 \mathrm{E}-03$ & 2 & 42 & 5 \\
Chromosome condensation in prometaphase & $2.95 \mathrm{E}-03$ & 2 & 43 & 5 \\
Sister chromatid cohesion & $3.23 \mathrm{E}-03$ & 2 & 45 & 4 \\
Nucleotide metabolism & & & 5 \\
TTP metabolism & $2.19 \mathrm{E}-03$ & 2 & 37 & 5 \\
dCTP/dUTP metabolism & $2.82 \mathrm{E}-03$ & 2 & 42 & 5 \\
\hline
\end{tabular}




\section{Table 2a}

Effects of UROtsa genotype exposed to $50 \mu \mathrm{M}$ iAs at the pathway level

\begin{tabular}{|c|c|c|c|c|}
\hline Pathway & $P$-Value & $\begin{array}{l}\text { No. of genes } \\
\text { expressed }\end{array}$ & $\begin{array}{l}\text { No. of genes in } \\
\text { pathway }\end{array}$ & Percentage (\%) \\
\hline \multicolumn{5}{|l|}{ Cell cycle control } \\
\hline Sister chromatid cohesion & $2.24 \mathrm{E}-02$ & 5 & 45 & 11 \\
\hline \multicolumn{5}{|l|}{ Cell death/Apoptosis } \\
\hline TNFR1 signaling pathway & $2.44 \mathrm{E}-02$ & 5 & 46 & 11 \\
\hline Caspase cascade activation by FADD and RIPK proteins & $3.00 \mathrm{E}-02$ & 4 & 33 & 12 \\
\hline \multicolumn{5}{|l|}{ Regulation of transcription } \\
\hline $\begin{array}{l}\text { Role of heterochromatin protein } 1 \text { (HP1) family in } \\
\text { transcriptional silencing }\end{array}$ & $4.16 \mathrm{E}-02$ & 5 & 53 & 9 \\
\hline $\begin{array}{l}\text { Formation of } \operatorname{Sin} 3 \mathrm{~A} \text { and } \mathrm{NuRD} \text { complexes and their role } \\
\text { in transcription regulation }\end{array}$ & $4.77 \mathrm{E}-02$ & 5 & 55 & 9 \\
\hline \multicolumn{5}{|l|}{ Function groups/kinases } \\
\hline MAPK signaling cascade. Activation of MSK & $1.33 \mathrm{E}-02$ & 4 & 26 & 15 \\
\hline \multicolumn{5}{|l|}{ Metabolism—amino acid } \\
\hline Proline metabolism & $1.73 \mathrm{E}-02$ & 4 & 28 & 14 \\
\hline TCA & $3.38 \mathrm{E}-02$ & 3 & 20 & 15 \\
\hline Arginine metabolism & $4.71 \mathrm{E}-02$ & 4 & 38 & 11 \\
\hline \multicolumn{5}{|l|}{ Metabolism—lipid } \\
\hline Globo-(isoglobo) series GSL metabolism & $1.84 \mathrm{E}-02$ & 3 & 16 & 19 \\
\hline Ganglioside Metabolism & 4.83E-02 & 2 & 10 & 20 \\
\hline \multicolumn{5}{|l|}{ Metabolism of mediators } \\
\hline Polyamine metabolism & 8.60E-03 & 4 & 23 & 17 \\
\hline
\end{tabular}


Table 2b

Effects on pathways due to Urotsa/F35 genotype exposed to $50 \mu \mathrm{M}$ iAs

\begin{tabular}{|c|c|c|c|c|}
\hline Pathway & $P$-Value & $\begin{array}{r}\text { No. of genes } \\
\text { expressed }\end{array}$ & $\begin{array}{r}\text { No. of genes in } \\
\text { pathway }\end{array}$ & Percentage (\%) \\
\hline \multicolumn{5}{|l|}{ Cell adhesion } \\
\hline FAK signaling & $1.57 \mathrm{E}-03$ & 13 & 70 & 19 \\
\hline Ephrins signaling & $2.47 \mathrm{E}-02$ & 9 & 58 & 16 \\
\hline Reverse signaling by ephrin B & 4.31E-02 & 11 & 84 & 13 \\
\hline \multicolumn{5}{|l|}{ Cell death/Apoptosis } \\
\hline BAD phosphorylation & $1.94 \mathrm{E}-02$ & 12 & 84 & 14 \\
\hline $\begin{array}{l}\text { Cytoplasm/mitochondrial transport of proapoptotic proteins Bad } \\
\text { and Bax }\end{array}$ & $3.14 \mathrm{E}-02$ & 8 & 51 & 16 \\
\hline \multicolumn{5}{|l|}{ Growth and differentiation } \\
\hline Angiotensin activation of ERK & $5.09 \mathrm{E}-02$ & 8 & 56 & 14 \\
\hline Putative erythropoietin signaling pathway & $1.26 \mathrm{E}-02$ & 9 & 52 & 17 \\
\hline Putative erythropoietin signaling pathway & $3.40 \mathrm{E}-02$ & 10 & 71 & 14 \\
\hline FGF-family signaling & $3.55 \mathrm{E}-02$ & 6 & 34 & 18 \\
\hline PIP3 signaling in & $9.08 \mathrm{E}-03$ & 12 & 76 & 16 \\
\hline GDNF signaling & 8.19E-03 & 6 & 25 & 24 \\
\hline \multicolumn{5}{|l|}{ Immune response } \\
\hline Signaling pathway mediated by IL- 6 and IL-1 & $1.44 \mathrm{E}-02$ & 7 & 36 & 19 \\
\hline IL6 signaling pathway & $2.71 \mathrm{E}-02$ & 6 & 32 & 19 \\
\hline IL22 signaling pathway & $2.80 \mathrm{E}-02$ & 5 & 24 & 21 \\
\hline BCR pathway & 4.98E-02 & 11 & 86 & 13 \\
\hline \multicolumn{5}{|l|}{ Regulation of transcription } \\
\hline Receptor-mediated HIF regulation & $2.50 \mathrm{E}-02$ & 7 & 40 & 18 \\
\hline Transcription factor Tubby signaling pathways & $3.19 \mathrm{E}-02$ & 7 & 42 & 17 \\
\hline \multicolumn{5}{|l|}{ Cyto/chemokines } \\
\hline CXCR4 signaling pathway & $1.63 \mathrm{E}-03$ & 11 & 54 & 20 \\
\hline CXCR4 signaling via second messenger & $4.24 \mathrm{E}-02$ & 8 & 54 & 15 \\
\hline \multicolumn{5}{|l|}{ G-proteins/GPCR } \\
\hline $\begin{array}{l}\text { A2BR signaling via G-beta/gamma dimer. RGS and CaM-related } \\
\text { GIRK regulation }\end{array}$ & $1.00 \mathrm{E}-02$ & 6 & 26 & 23 \\
\hline G-Protein alpha-q signaling cascades & $1.02 \mathrm{E}-02$ & 10 & 59 & 17 \\
\hline G-Protein beta/gamma signaling cascades & $1.60 \mathrm{E}-02$ & 9 & 54 & 17 \\
\hline $\begin{array}{l}\text { Membrane trafficking and signal transduction of G-alpha (i) } \\
\text { heterotrimeric G-protein }\end{array}$ & $1.67 \mathrm{E}-02$ & 7 & 37 & 19 \\
\hline G-Protein alpha-i signaling cascades & $2.82 \mathrm{E}-02$ & 8 & 50 & 16 \\
\hline $\begin{array}{l}\text { Rhodopsin phototransduction cascade in retina - the key role of } \\
\mathrm{Ca} 2+\text { transport }\end{array}$ & $3.32 \mathrm{E}-02$ & 9 & 61 & 15 \\
\hline $\begin{array}{l}\text { A2BR signaling via G-alpha-q: PRKCA - RSK \& JNK specific } \\
\text { pathways }\end{array}$ & $3.85 \mathrm{E}-02$ & 8 & 53 & 15 \\
\hline G-Protein alpha-12 signaling pathway & $3.85 \mathrm{E}-02$ & 8 & 53 & 15 \\
\hline CDC42 in cellular processes & $1.01 \mathrm{E}-02$ & 12 & 77 & 16 \\
\hline CREB pathway & $1.15 \mathrm{E}-02$ & 16 & 117 & 14 \\
\hline
\end{tabular}




\begin{tabular}{|c|c|c|c|c|}
\hline Pathway & $P$-Value & $\begin{array}{l}\text { No. of genes } \\
\text { expressed }\end{array}$ & $\begin{array}{r}\text { No. of genes in } \\
\text { pathway }\end{array}$ & Percentage $(\%)$ \\
\hline RAN regulation pathway & $1.20 \mathrm{E}-02$ & 8 & 43 & 19 \\
\hline \multicolumn{5}{|l|}{ Function groups/kinases } \\
\hline $\begin{array}{l}\text { MAPK cascade. Part II, Map } 2 \text { - MAP4K2-4 - ERK/JNK pathway; } \\
\text { interaction with MEK1/2 }\end{array}$ & $1.57 \mathrm{E}-03$ & 10 & 46 & 22 \\
\hline $\begin{array}{l}\text { MAPK cascade. Part II, Map } 3 \text { - MAP4K2-4 - JNK/ERK5 } \\
\text { pathway. Interaction with P-38 Cascade }\end{array}$ & $2.34 \mathrm{E}-02$ & 6 & 31 & 19 \\
\hline MAPK cascade. Part I. Map 1. ERK-related pathways & $3.48 \mathrm{E}-02$ & 8 & 52 & 15 \\
\hline Role PKA in cytoskeleton reorganization & $3.70 \mathrm{E}-02$ & 11 & 82 & 13 \\
\hline \multicolumn{5}{|l|}{ Function groups/second messenger } \\
\hline Pleckstrin homology proteins interactions & $3.83 \mathrm{E}-02$ & 5 & 26 & 19 \\
\hline \multicolumn{5}{|l|}{ Metabolic maps/Nucleotide metabolism } \\
\hline GTP-XTP metabolism & $2.74 \mathrm{E}-02$ & 9 & 59 & 15 \\
\hline \multicolumn{5}{|l|}{ Regulation of metabolism } \\
\hline Insulin receptor signaling pathway & $3.58 \mathrm{E}-02$ & 7 & 43 & 16 \\
\hline
\end{tabular}




\section{Table 3a}

Effects on pathways by $1 \mu \mathrm{M}$ iAs

\begin{tabular}{|c|c|c|c|c|}
\hline Pathway & $P$-Value & $\begin{array}{l}\text { No. of genes } \\
\text { expressed }\end{array}$ & $\begin{array}{r}\text { No. of genes in } \\
\text { pathway }\end{array}$ & Percentage $(\%$ \\
\hline \multicolumn{5}{|l|}{ Cell adhesion } \\
\hline Plasmin signaling & $5.38 \mathrm{E}-02$ & 1 & 47 & 2 \\
\hline \multicolumn{5}{|l|}{ Growth and differentiation } \\
\hline VEGF signaling via VEGFR2—generic cascades & 4.93E-02 & 1 & 43 & 2 \\
\hline \multicolumn{5}{|l|}{ Immune response } \\
\hline IFN alpha/beta signaling pathway & $3.47 \mathrm{E}-02$ & 1 & 30 & 3 \\
\hline \multicolumn{5}{|l|}{ Transcription factors } \\
\hline Role of AP-1 in regulation of cellular metabolism & 4.93E-02 & 1 & 43 & 2 \\
\hline \multicolumn{5}{|l|}{ Amino acid metabolism } \\
\hline Methionine-cysteine-glutamate metabolism & $2.09 \mathrm{E}-02$ & 1 & 18 & 6 \\
\hline \multicolumn{5}{|l|}{ Lipid metabolism } \\
\hline LDL metabolism during development of fatty streak lesion & $2.20 \mathrm{E}-02$ & 2 & 199 & 1 \\
\hline \multicolumn{5}{|l|}{ Vitamin and cofactor metabolism } \\
\hline Glutathione metabolism & 7.83E-04 & 2 & 36 & 6 \\
\hline Heme metabolism & $4.60 \mathrm{E}-02$ & 1 & 40 & 3 \\
\hline \multicolumn{5}{|l|}{ Regulation of metabolism } \\
\hline Transcription regulation of amino acid metabolism & $4.82 \mathrm{E}-02$ & 1 & 42 & 2 \\
\hline RhoA regulation pathway (extension, GEFs/GAPs) & $3.92 \mathrm{E}-02$ & 1 & 34 & 3 \\
\hline
\end{tabular}


Table 3b

Effects of $50 \mu \mathrm{M}$ iAs at the pathway level

\begin{tabular}{|c|c|c|c|c|}
\hline Pathway & $P$-Value & $\begin{array}{r}\text { No. of genes } \\
\text { expressed }\end{array}$ & $\begin{array}{l}\text { No. of genes in } \\
\text { pathway }\end{array}$ & Percentage $(\%)$ \\
\hline \multicolumn{5}{|l|}{ Cell adhesion } \\
\hline Chemokines and adhesion & $1.35 \mathrm{E}-05$ & 57 & 209 & 27 \\
\hline TGF, WNT and cytoskeletal remodeling & $3.16 \mathrm{E}-05$ & 55 & 205 & 27 \\
\hline Cytoskeleton remodeling & 4.11E-05 & 49 & 178 & 28 \\
\hline Integrin outside-in signaling & $1.20 \mathrm{E}-04$ & 26 & 79 & 33 \\
\hline Fibronectin-binding integrins in cell motility & $5.00 \mathrm{E}-03$ & 16 & 52 & 31 \\
\hline Integrin-mediated cell adhesion & $9.74 \mathrm{E}-03$ & 24 & 94 & 26 \\
\hline \multicolumn{5}{|l|}{ Cell cycle control } \\
\hline Chromosome condensation in prometaphase & $1.84 \mathrm{E}-09$ & 24 & 43 & 56 \\
\hline Sister chromatid cohesion & $6.29 \mathrm{E}-09$ & 24 & 45 & 53 \\
\hline Start of the mitosis & $3.24 \mathrm{E}-08$ & 27 & 58 & 47 \\
\hline Brca1 as transcription regulator & $4.34 \mathrm{E}-08$ & 18 & 30 & 60 \\
\hline Start of DNA replication in early S phase & $4.00 \mathrm{E}-07$ & 21 & 43 & 49 \\
\hline Transition and termination of DNA replication & $1.75 \mathrm{E}-06$ & 18 & 36 & 50 \\
\hline ATM/ATR regulation of G1/S checkpoint & $2.64 \mathrm{E}-05$ & 18 & 42 & 43 \\
\hline Role of Brca1 and Brca2 in DNA repair & $3.38 \mathrm{E}-05$ & 17 & 39 & 44 \\
\hline Role APC in cell cycle regulation & $3.41 \mathrm{E}-05$ & 21 & 54 & 39 \\
\hline Role SCF complex in cell cycle regulation & $5.02 \mathrm{E}-05$ & 17 & 40 & 43 \\
\hline DNA-damages-induced responses & $6.47 \mathrm{E}-05$ & 7 & 9 & 78 \\
\hline ATM/ATR regulation of G2/M checkpoint & $1.30 \mathrm{E}-04$ & 13 & 28 & 46 \\
\hline The metaphase checkpoint & $2.61 \mathrm{E}-04$ & 15 & 37 & 41 \\
\hline Regulation of G1/S transition & $7.48 \mathrm{E}-04$ & 20 & 61 & 33 \\
\hline Spindle assembly and chromosome separation & $3.89 \mathrm{E}-03$ & 23 & 83 & 28 \\
\hline Cell cycle (generic schema) & $4.18 \mathrm{E}-03$ & 9 & 22 & 41 \\
\hline Role of NFBD1 in DNA damage response & $5.99 \mathrm{E}-03$ & 6 & 12 & 50 \\
\hline \multicolumn{5}{|l|}{ Cell death/Apoptosis } \\
\hline Caspases cascade & $3.41 \mathrm{E}-06$ & 17 & 34 & 50 \\
\hline $\begin{array}{l}\text { Caspases cascade activation by granzyme and other signaling } \\
\text { proteins }\end{array}$ & $2.14 \mathrm{E}-05$ & 15 & 31 & 48 \\
\hline Antiapoptotic Function of TRADD/TRAF2 complex & $3.44 \mathrm{E}-05$ & 15 & 32 & 47 \\
\hline FAS signaling cascades. Part 2 & $1.48 \mathrm{E}-04$ & 17 & 43 & 40 \\
\hline TNFR1 signaling pathway & $3.85 \mathrm{E}-04$ & 17 & 46 & 37 \\
\hline Caspases activation via nuclear import & $3.92 \mathrm{E}-04$ & 12 & 27 & 44 \\
\hline Role of IAP-proteins in apoptosis & $6.87 \mathrm{E}-04$ & 14 & 36 & 39 \\
\hline p53-dependent apoptosis & $9.20 \mathrm{E}-04$ & 13 & 33 & 39 \\
\hline $\begin{array}{l}\text { Cytoplasm/mitochondrial transport of proapoptotic proteins Bid, } \\
\text { Bmf, and Bim }\end{array}$ & $1.74 \mathrm{E}-03$ & 13 & 35 & 37 \\
\hline TRAF proteins signaling network & $1.74 \mathrm{E}-03$ & 13 & 35 & 37 \\
\hline p38-MAPK cascade activation via FAS1 and TNFR1 & $2.32 \mathrm{E}-03$ & 11 & 28 & 39 \\
\hline DNA-damages-induced apoptosis & $4.81 \mathrm{E}-03$ & 7 & 15 & 47 \\
\hline
\end{tabular}

Hum Exp Toxicol. Author manuscript; available in PMC 2012 December 03. 


\begin{tabular}{|c|c|c|c|c|}
\hline Pathway & $P$-Value & $\begin{array}{r}\text { No. of genes } \\
\text { expressed }\end{array}$ & $\begin{array}{l}\text { No. of genes in } \\
\text { pathway }\end{array}$ & Percentage (\%) \\
\hline Caspase cascade activation by FADD and RIPK proteins & $9.82 \mathrm{E}-03$ & 11 & 33 & 33 \\
\hline \multicolumn{5}{|l|}{ Growth and differentiation } \\
\hline EGF signaling pathway & $8.49 \mathrm{E}-03$ & 18 & 64 & 28 \\
\hline Estrogen receptor signaling pathway & $3.44 \mathrm{E}-04$ & 14 & 34 & 41 \\
\hline Notch Signaling Pathway & 5.19E-03 & 13 & 39 & 33 \\
\hline PDGF signaling via STATs and NF- $\kappa B$ & $6.60 \mathrm{E}-03$ & 13 & 40 & 33 \\
\hline IGF-RI signaling & $6.64 \mathrm{E}-03$ & 20 & 72 & 28 \\
\hline $\begin{array}{l}\text { Receptors. Part B. INSR—pleckstrin homology proteins } \\
\text { interactions }\end{array}$ & 7.13E-03 & 12 & 36 & 33 \\
\hline $\begin{array}{l}\text { Receptors. Part E. EPOR - pleckstrin homology proteins } \\
\text { interactions }\end{array}$ & $9.07 \mathrm{E}-03$ & 12 & 37 & 32 \\
\hline \multicolumn{5}{|l|}{ Immune response } \\
\hline IL9 signaling pathway & $9.82 \mathrm{E}-03$ & 11 & 33 & 33 \\
\hline \multicolumn{5}{|l|}{ Regulation of transcription } \\
\hline $\begin{array}{l}\text { Formation of } \operatorname{Sin} 3 \mathrm{~A} \text { and } \mathrm{NuRD} \text { complexes and their role in } \\
\text { transcription regulation }\end{array}$ & 4.83E-04 & 19 & 55 & 35 \\
\hline $\begin{array}{l}\text { Role of heterochromatin protein } 1 \text { (HP1) family in transcriptional } \\
\text { silencing }\end{array}$ & $2.38 \mathrm{E}-03$ & 17 & 53 & 32 \\
\hline RalA regulation pathway & $1.74 \mathrm{E}-03$ & 13 & 35 & 37 \\
\hline Regulation of $\mathrm{CDC} 42$ activity & 8.17E-03 & 9 & 24 & 38 \\
\hline \multicolumn{5}{|l|}{ Function groups/kinases } \\
\hline MAPK signaling cascade. Activation of MSK & $4.36 \mathrm{E}-03$ & 10 & 26 & 38 \\
\hline \multicolumn{5}{|l|}{ Function groups/phosphotases } \\
\hline PTEN pathway & $9.03 \mathrm{E}-03$ & 16 & 55 & 29 \\
\hline \multicolumn{5}{|l|}{ Second messenger } \\
\hline $\begin{array}{l}\text { Receptors. Part F. KIT-pleckstrin homology (PH) proteins } \\
\text { interactions }\end{array}$ & 4.23E-03 & 12 & 34 & 35 \\
\hline $\begin{array}{l}\text { PH proteins participation in RTKs adaptor complexes formation } \\
\text { and intermediation with focal adhesion complex. Part } 2\end{array}$ & $8.49 \mathrm{E}-03$ & 18 & 64 & 28 \\
\hline $\begin{array}{l}\text { PH proteins participation in different RTKs adaptor complexes } \\
\text { formation and intermediation with focal adhesion complex. Part } 1\end{array}$ & $1.01 \mathrm{E}-02$ & 18 & 65 & 28 \\
\hline \multicolumn{5}{|l|}{ Transcription factors } \\
\hline Regulation of lipid metabolism via LXR, NF-Y and SREBP & $5.53 \mathrm{E}-03$ & 12 & 35 & 34 \\
\hline \multicolumn{5}{|l|}{ Nucleotide metabolism } \\
\hline CTP/UTP metabolism & $8.40 \mathrm{E}-05$ & 23 & 65 & 35 \\
\hline ATP/ITP metabolism & $1.36 \mathrm{E}-04$ & 24 & 71 & 34 \\
\hline dCTP/dUTP metabolism & $3.81 \mathrm{E}-04$ & 16 & 42 & 38 \\
\hline GTP-XTP metabolism & 4.60E-04 & 20 & 59 & 34 \\
\hline dATP/dITP metabolism & $1.48 \mathrm{E}-03$ & 17 & 51 & 33 \\
\hline TTP metabolism & $3.09 \mathrm{E}-03$ & 13 & 37 & 35 \\
\hline dGTP metabolism & $6.60 \mathrm{E}-03$ & 13 & 40 & 33 \\
\hline \multicolumn{5}{|l|}{ Steroid metabolism } \\
\hline Cholesterol Biosynthesis & $1.11 \mathrm{E}-04$ & 11 & 21 & 52 \\
\hline
\end{tabular}




\begin{tabular}{lrrrr}
\hline Pathway & $\boldsymbol{P}$-Value & $\begin{array}{c}\text { No. of genes } \\
\text { expressed }\end{array}$ & $\begin{array}{l}\text { No. of genes in } \\
\text { pathway }\end{array}$ & Percentage (\%) \\
\hline Ubiquinone metabolism & $1.47 \mathrm{E}-05$ & 25 & 67 & 37 \\
\hline
\end{tabular}




\section{Table 4a}

Functional gene cluster associated with methylating UROtsa/F35 cells exposed to $1 \mu \mathrm{M}$ iAs ${ }^{\mathrm{III}}$

\begin{tabular}{ll}
\hline NM_004526 & mcm2 minichromosome preservation deficient 2, mitotin (S. cerevisiae) \\
NM_002592 & proliferating cell nuclear antigen \\
NM_005483 & chromatin assembly factor 1, subunit a (p150) \\
NM_002689 & polymerase (dna directed), alpha 2 (70 kDa subunit) \\
NM_003504 & cdc45 cell division cycle 45-like (S. cerevisiae) \\
\hline
\end{tabular}


Table 4b

Functional gene cluster associated with non-methylating UROtsa cells exposed to $1 \mu \mathrm{M}$ iAs ${ }^{\mathrm{III}}$

\begin{tabular}{ll}
\hline NM_005953 & metallothionein 2a \\
NM_175617 & metallothionein 1e (functional) \\
NM_005947 & metallothionein 1b (functional) \\
NM_005950, NM_176870 & metallothionein 1g \\
NM_005952 & metallothionein 1x \\
\hline
\end{tabular}

Hum Exp Toxicol. Author manuscript; available in PMC 2012 December 03. 